painting'. A faculty was granted and the proceeds of sale were to be applied to the church repairs account. [Alexander McGregor]

doi:10.1017/So956618X11000548

\author{
Jakóbski v Poland \\ European Court of Human Rights: December 2010 \\ Prisoner - Buddhism - meat-free diet - Article 9
}

The applicant was convicted of rape in June 2003 and sentenced to eight years' imprisonment. He made numerous requests to be served meat-free meals in accordance with his dietary requirements as a Buddhist. The prison eventually agreed to provide him with a pork-free diet in January 2006, as it did for six Muslim prisoners. In April 2006 a prison doctor considered the applicant's dermatological problems had subsided and that the pork-free diet could be withdrawn. The applicant renewed his requests for a meat-free diet. His request was supported by the Buddhist Mission in Poland. This request was rejected by the prison in October 2006. The applicant was later advised that the only special prison diet available was a pork-free one and that provision of individual diets in conformity with religious requirements was not possible owing to kitchen under-staffing. In March 2009 the applicant was transferred to another prison, where his meat-free diet requests were also refused.

In the European Court of Human Rights ([2010] ECHR 18429/06) the applicant argued a violation of Article 9 and, because other religious groups were permitted special diets in prison, Article 14. The court did not examine arguments under Article 14, as it was satisfied that Article 9 had been violated. Buddhism was a major world religion and religious dietary requirements could be regarded as directly motivated or inspired by religion: Cha'are Shalom Ve Tsedek v France [2000] ECHR 27417/95. Accordingly, the refusal to provide the applicant with a religious meat-free diet was an interference under Article 9(1). In addressing Article 9(2) the court recognised that particular dietary arrangements for one prisoner could have financial implications for institutions and indirect implications for the quality of treatment of other inmates. Nevertheless, a fair balance had not been struck between the competing interests. The applicant's meal requests were for vegetarian food, which did not have to be prepared, cooked and served in any prescribed ways, nor were any special food products required. The court decided that no disruption to the management of the prison would have followed from the 
applicant's request, nor any decline in the standards of meals served to the other prisoners. [Matthew Gibson]

doi:10.1017/So956618X1100055X

\author{
Re Scholemoor Cemetery, Bradford \\ Bradford Consistory Court: Walford Ch, January 2011 \\ Exhumation - no exceptional circumstances
}

Applying Re Blagdon Cemetery [2002] Fam 299, the chancellor held that a desire to fulfil the wish of the petitioner's mother that her husband's ashes should be placed with hers did not amount to exceptional circumstances such as to justify the exhumation and removal of his cremated remains from one cemetery to another. The chancellor held that 'a wish (however understandable) to reverse a decision made several years ago, which although regretted since was perfectly valid at the time it was made, is not sufficient, in my judgment, for these purposes'. [Alexander McGregor]

\title{
Hall and Preddy v Bull and Bull
}

Bristol County Court: HHJ Rutherford, January 2011

Discrimination - Equality Act - religious belief

The claimants brought an action against the defendants under the Equality Act (Sexual Orientation) Regulations 2007 for a declaration and damages for discrimination on the grounds of their sexual orientation. The claimants were two men who were in a civil partnership who had, by telephone, booked a double room at the defendants' hotel. The defendants ran their hotel (which was also their home) along Christian principles and their policy, which was stated in clear terms on their website but of which the claimants were unaware, was to let double rooms only to heterosexual married couples. On arrival at the hotel, the defendants refused to allow the claimants to use a double room. Both parties relied upon their rights under Articles 8 (right to respect for their private and family life) and 14 (right not to be discriminated against) of the ECHR. The defendants relied upon their right to manifest their religion under Article 9 of the ECHR. The judge accepted that the running of an hotel along Christian principles could be regarded as manifesting one's religion. The judge held that the claimants had been directly and indirectly 